\title{
Temporal Hydrogeochemical Dynamics and Source Apportionment in Groundwater of a Complex Lithology.
}

\section{Ganesh N}

Annamalai University

Vasudevan U

Annamalai University

Devaraj N ( $\sim$ devarajndr@gmail.com )

Annamalai University

Mahalakshmi K

Sastra University

\section{Banajarani Panda}

Annamalai University

\section{Dhiraj Kr Singh}

Grass Roots Research and Creation India (P) Ltd., Delhi

\section{Research Article}

Keywords: Groundwater, Hydrochemistry, Gibb's plot, Piper Plot, Factor analysis

Posted Date: November 30th, 2021

DOI: https://doi.org/10.21203/rs.3.rs-1021408/v1

License: (c) (1) This work is licensed under a Creative Commons Attribution 4.0 International License. Read Full License 


\section{Abstract}

The present research reports the level of major ions and other physical parameters like $\mathrm{pH}, \mathrm{EC}$ and TDS and possible sources of contamination in groundwater from south India. A total of 138 groundwater samples were collected during four different seasons and analyzed for physical parameters and other major ions. Many samples are above or approaching the recommended level of ions for safe drinking water. The groundwater quality has been determined by considering 11 parameters and classified into 5 different categories based upon water quality index (WQI) value. The groundwater of the study area is approaching towards pollution which has to consider for future management of the resource. Different geochemical diagrams like Gibbs and Piper are used to evaluate the process affecting the composition of groundwater. Again, the geostatistical techniques applied to confirm the processes through an integrated approach. Based on result of geochemical investigation, the contamination sources in the groundwater of this region are likely to be from (a) Anthropogenic activities (b) Weathering (c) Agricultural fertilizers. Continuous consumption of such water may pose serious health risk to the residents.

\section{Introduction}

Water is an indispensable source of nature and it acts as an elixir of life to both mankind and other species. Mismanagement of this resource for various purposes like domestic, agriculture and industrial, result in scarcity and quality deterioration, which has become a major issue globally. Though there are many sources of water like surface (river, lake and pond), groundwater and coastal water, only groundwater is considered as the potentially available source to human use for various purposes. However, potential of this resource depends upon various factors like frequency of rainfall, climatic condition, availability of surface water, proximity to the coastal area etc, which tend to vary with season and geographical setting of an area. Therefore, conserving water as well as protecting it from pollution has become the need of the day. Thus, study on groundwater quality has become very significant to plan the strategies for conservation of water resources. Hydrochemical properties of groundwater are directly related to the quality study of groundwater and proved to be an important factor in water quality studies (Atwia et al., 1997; Fischer and Mullican 1997; Thilagavathi 2012; Vasudevan 2017; Thivya 2019; Devaraj 2020). The association between the geological materials and groundwater quality has been studied by many researchers and they have recognized many other factors that influence groundwater chemistry, such as the aquifer properties, waste water and saline water infiltration, aquifer lithology etc (Lavitt et al.1997;Chidambarametal. 2008 and 2010 Vasanthvigar et al.2010;Vijayakumar et al. 2016; Pandaetal 2018a; Devaraj et al. 2019). Numerous studies on water quality issues and its causes are reported globally (Ramanathan et al. 2001; Chidambaram et al. 2005 and 2013; Karmegam et al. 2011; Nepolian 2016 Vetrimurugan 2020). There are different techniques used for a detail hydrochemical study of groundwater such as 1 . Statistical analysis to determine the factors responsible for variation in water chemistry (Panda et al. 2018b) 2. Identification of groundwater recharge potential zone by remote sensing in association with GIS techniques (Chidamabaram 2019), and 3. Interpretation of data by using various hydrochemical standard diagrams like Piper, (1944) Durov, (1948); Handa, (1965) and Jhonson 
(1975) Stiff, (1951); (1972) and Collins, (1975) diagrams). The South Indian aquifers are basically considered in three major aquifer types (1) inland (2) coastal sedimentary (3) hardrockaquifers. There are certain critical geographical locations which are hoisted along the hard rockandsedimentaryaquifercontact. Theseregionsrepresentacomplexlithologywithdifferentlithounits (Devraj et al. 2020), which affects the water level (Panda et al. 2020), residence time (Thilagavathi et al. 2018), groundwater flow (Thivya et al 2019.), aquifer interaction (Devaraj et al 2021), recharge (Panda et al. 2020), and land use pattern (Panda et al. 2021) of a region. There are few studies on similar geographical conditions adjacent to the study are addressing the uranium concentration in the groundwater and their geochemical evolutions (Adithya et al 2019, 2020). The current study area is one such located in the hard rock and sedimentary contact. The rapid increase in population of this agriculturally rich region with industrial housings makes it very essential to study about the current status of groundwater quality. Agriculture is the major occupation in the present study area, and serves as the back bone of the economy especially region and contributes significantly to the state's economy. Hence, understanding the groundwater quality fluctuation and the responsible factors for this fluctuation is important for the study region. The assessment of varied composition of hydrochemical parameters in groundwater has been proved to be beneficial to solve the many water quality issues. Thus, for deriving an appropriate management strategy, a detailed study on the groundwater quality, geochemical source apportionment and its spatial variation is essential. Hence, this study attempts to understand the hydro chemical processes accountable for the variation in groundwater chemistry.

\section{Study Area}

The area for the present study is located in the central part of Tamil Nadu state with an aerial extent of $1755 \mathrm{sq}$. $\mathrm{km}$ within the latitude of $11^{\circ} 04-11^{\circ} 52 \mathrm{~N}$ and longitude of $78^{\circ} 62-79^{\circ} 17 \mathrm{E}$. The area is comprised of 121 village panchayats, four town panchayats and one municipality. Stratigraphically the region is constituted by Achaean, Cretaceous, Tertiary and Quaternary formation. The clay, sandstone, and micaceous sandstone from the Upper Jurassic to the Lower Cretaceous, unconformably overlaid above the crystalline rocks, and both rock types can be found in Karai. Calcareous sandstone and thin bands of shell limestone make up the lower Kulakanatham Formation (CGWB, 2009). Formations of upper Gondwana age are also found in a limited spatial extent. The Achaeans consist of biotite, hornblende gneisses, Charnockite etc. Upper Jurassic formations are represented by equivalents of Gondwana in small patches in parts of Perambalur taluk. Charnockite and Gneisses are the primary litho units of the hard rock terrain, with quartz and pegmatite intrusion (Fig. 1). Tertiary formation includes Cuddalore Sandstone, mottled ferruginous clays, and pebbles, white Sandy Limestones and Sandstones with Fossils, Calcareous mottled Sandstones with Fossils, Shell Limestones, Clays, Basal Limestone and Sandy Beds with Fossils. Vellar is the main river serving to the agricultural activities in the region and Marudaiyar river traverse through Ariyalur taluk and joins the Coleroon river. The tributaries of the Vellar and Marudaiyar rivers, Kallar and Chinnar, drains through Perambalur region of the study area. The Kallar and Marudaiyar have also a significant contribution to the agricultural activities of the study area. These rivers are all non-perennial and spotted with numerous tanks that act as the primary source of drinking 
water, with any surplus water overflows to feed the adjacent tanks. In the sedimentary tract, the drainage system is dendritic, and in the crystalline area, it is dendritic to trellis. There is a semi-arid climate (i.e., hot in summer \& cool in winter) in this region. The hottest part of the summer lasts from March to May, with a maximum temperature goes up to $40^{\circ} \mathrm{C}$. The winter season lasts two months, from January to February. The area receives an annual average rainfall of $908 \mathrm{~mm}$, during the northeast monsoon (NEM) contributing $52 \%$ of the total rainfall, however $34 \%$ of total rainfall received during southwest monsoon (SWM) and rest $14 \%$ of total rainfall considered to be from intermittent rain showers. The observation of the rainfall data for the five years from 2011-2015 (Fig. 2) shows that less rainfall was received during 2012. There has been an increase of rainfall during 2015. But during 2011, 2013 and 2014 the average annual rainfall remains the same.

\section{Methodology}

A total of 168 number (42 samples per each season) of groundwater samples were sampled during January, May, August, and November, of the year 2016, representing Post Monsoon (POM), Pre monsoon (PRM), South West Monsoon (SWM) and North East Monsoon (NEM), respectively. The collected samples were filtered and measured for Physical parameters like EC, pH and TDS in field and later on after bring to laboratory the samples were again crosschecked for all the physical parameters. Consequently, the samples were stored at $4^{0} \mathrm{C}$ until hydrochemical analysis. Major ions such as $\mathrm{HCO}_{3}{ }^{-}, \mathrm{Cl}^{-}, \mathrm{SO}_{4}{ }^{2-}, \mathrm{PO}_{4}{ }^{3}$, $\mathrm{NO}_{3}{ }^{-}, \mathrm{F}-, \mathrm{H}_{4} \mathrm{SiO}_{4}, \mathrm{Ca}^{2+}, \mathrm{Mg}^{2+}, \mathrm{Na}^{+}$, and $\mathrm{K}^{+}$were measured by following the standard procedure as detailed in APHA 1995. The major ions Each sample was analyzed three times for both physical and the average was accounted for accuracy. The precision of data analyzed was calculated by using equation 1 (Freeze and Cherry, 1979) by determining ionic balance error (IBE) which was observed to be within $5-10 \%$. The specifications of the analytical methodology are detailed in the table 1. Values that are greater than the limit of detection are diluted and measured subsequently by multiplying with the dilution factor. The PCA (Principal Component Analysis) and the Pearson correlation analysis were determined by Social Sciences Statistical Package (SPSS), version 17.0. Map info (version: Professional 8.5) with vertical mapper was used to prepare the spatial distribution maps. The water quality parameters (Table 1) were obtained by feeding the hydrochemical and physical results as the inputs to the program 'CHIDAM' (Chidambaram 2020).

\section{Result And Discussion}

\section{Water Chemistry}

\section{Physical parameters:}

The $\mathrm{pH}$ of the groundwater in the study area ranges from 6.21 to 8.38 for all the four different seasons. The lowest pH is detected in NEM, and highest pH in PRM (Table 2). Similarly highest value of EC is noted in NEM lowest in PRM. However, the EC of the samples are higher in few samples irrespective of seasons. Based on the classification given by Saxena et al., (2003) the EC value of the study area, the 
groundwater has been divided into three classes (1) fresh (<1,500 $\mu \mathrm{S} / \mathrm{cm}),(2)$ brackish $(1,500-3,000$ $\mu \mathrm{S} / \mathrm{cm}$ ), and (3) saline $>3,000 \mu \mathrm{S} / \mathrm{cm}$. The number of samples falling within each category for four different seasons are noted in Table 3. The trend as observed in table 3 values fresh category of samples has a increasing value from POM, to NEM, SWM and PRM which may be attributed to the infrequent rainfall during PRM with respect to other seasons.

Considering the spatial distribution of EC of the groundwater samples (Fig 3),the higher values are noted in the northeast and a minor representations is observed in the southern region in all seasons. Northeast and southern part of the study area is covered with sedimentary rock units (Fig 1). The percolation of the domestic sewage infiltration along the flood plain of the Vellar River in the northeastern part may be expected to resulting in higher EC in this part. The EC was observed to be highest adjoining the river decreases with distance from the river increases. Ranjana and Champa Naverathna (2011) reported similar results in groundwaters of urban areas of Sri Lanka. Similarly, the lowest EC is noticed on the western side of the area irrespective of all the four seasons which is mainly covered with hard rock units (Fig 1). Hard rocks with fractured and weathered outcrops have a quick response to rainfall. During recharge, the significant ion concentration either dilutes or the dissolve chemical compounds found along the flow path (Vetrimurugan 2014,Panda et al. 2020). Rainfall recharge is considered to be as one of the leading controls on the seasonal fluctuation of EC. Recharge reduces the ionic concentration of groundwater whereas leaching, dissolution, and evaporation tend to increase ionic strength in general (Chidambaram et al. 2019).

The highest TDS is observed in NEM, and lowest values are noted in PRM. The TDS value of the study area has been categorized in to four categories based on the classification scheme given by Carrol (1962) and provided in Table 4. There are a few numbers of samples are observed in brackish water quality category for all four seasons and during NEM its highest (Table 4). However most of the samples are within fresh category

\section{Chemical parameters:}

The lowest concentration of $\mathrm{Ca}$ is observed in PRM whereas the highest concentration is noted in NEM (Table 2). Presence of Calcium in drinking water is reported to cause cardiovascular diseases, nervous system defects, and cancer. Calcium content in water gives it hardness which may create scales in pipes, encrustation of utensils and difficulty in soap lathering (Chidambaram et al 2010). NEM has the highest Mg concentration, while PRM has the lowest. The chief cation observed in the groundwater of the study area is sodium (Table 2) and is highest during PRM, whereas the lowest concentration is noted in POM season indicating the contribution from weathering of $\mathrm{Na}$ feldspar from the underlying rock types along with the dissolution and anthropogenic process (Vasudevan et al 2020). The highest concentration of $\mathrm{K}$ is noted in NEM, and lowest values are noted in PRM. The elevated level of $\mathrm{K}$ in groundwater is considered to be due to ion exchange or weathering of Fissile hornblende-biotite gneiss and Charnockite (Adithya 2016). 
$\mathrm{HCO}_{3}{ }^{-}$is one of the principal ions in the groundwater and concentration of $\mathrm{HCO}_{3}{ }^{-}$is highest in $\mathrm{NEM}$ and lowest in PRM (Table 2). The $\mathrm{HCO}_{3}{ }^{-}$in the groundwater of this region may have resulted from carbon dioxide of the atmosphere, soils and by suspension of carbonate rocks. Charnockite and Fissile Hornblende Biotite Gneiss rocks are predominant rock types in the study area which could be a possible source of $\mathrm{HCO}_{3}{ }^{-}$through the process of weathering (Devaraj et al 2018, Thivya 2019). Highest chloride concentration is noted during NEM and the lowest in PRM. The higher chloride concentration in the study area is may be from the wastage produced due to domestic activities. The $\mathrm{SO}_{4}{ }^{2-}$ concentration is highest in PRM and lowest in NEM (Table 2). The higher concentration is may be due to intensive anthropogenic activities. In minerals such as gypsum and marcasite, the amount of dissolved Sulphate ion varies (Anandhan, 2005). Other anthropogenic sources like bacterial fixation, fertilizer effect, tannery is also considered to be the major source for sulphate ion in the groundwater (Chidambaram et al., 2012). Similarly, the highest concentration of nitrate was higher in PRM season compared to other seasons. The intensive agricultural activities and domestic sewage may result in higher concentration of nitrate in the groundwater (Panda et al. 2018). Higher concentration of $\mathrm{H}_{4} \mathrm{SiO}_{4}$ was noted in PRM indicating rock dissolution in alkaline environment. Studies show that excess intake of silica usually results in silicosis (Cherry et al., 1997, 1998) It can also lead to enduring heart and lung disease. Parameters such as seasonal flux of precipitation, mechanical and chemical properties of bedrock, temperature and water table conditions determine the quantity of silica dissolved in groundwater (Dobrzynski, 2005). In general, all the parameters including physical and hydrochemical show higher concentration, exceeding to WHO standard for drinking purpose. Thus, it is recommended to assess the appropriateness of the groundwater characteristic of this region for the sustainable management of their source.

\section{Water quality Index}

For the groundwater samples in the study area, eleven water quality criteria were chosen to determine the water quality index. The factors were chosen for their respective importance in determining water quality for human consumption as well as their close proximity to data.. The guidelines are used to set the criteria according to the WHO (2011) standard for drinking water purpose. Each of the 11 parameters were assigned with a weight (wi) based on its relative significance with respect to overall drinking water quality which is considered to be between the integer 1 to 5 ( Table 5). Because of the significance of nitrate and TDS value in water quality evaluation, a maximum weight of 5 has been assigned, similarly $\mathrm{pH}, \mathrm{EC}, \mathrm{SO}_{4}{ }^{2}$ were assigned with $4, \mathrm{HCO}_{3}, \mathrm{Cl}$ with $3, \mathrm{Ca}^{2+}, \mathrm{Na}^{+}, \mathrm{K}^{+}$with 2 and $\mathrm{Mg}$ with 1 . The lowest weight is assigned to $\mathrm{Mg}$ because it might not be dangerous on its own consumption (Vasanthavigar et al. 2010, Thivya et al.2014; Thilagavthi et al. 2016).

In the following step, relative weights $(W i)$ were studied using the equation 1.

$n$

$W i=w i / \sum w i$ 
Where,

Wi, wi and n: relative weight, Each parameters weight and number of parameters respectively.

To determine a quality rating for each parameter, its concentration was divided by the corresponding water quality requirements (WHO, 2011) and multiplied by 100 (Eq. 2).

$q i=(\mathrm{Ci} / \mathrm{Si}) \times 100$,

qi, Ci and Si: quality rating, Chemical parameter's concentration of each water sample (mg/l)

and WHO standard limit for each parameter respectively.

To determine the WQI, the SI has to be calculated (Eq 3). Final WQI will be calculated by summing up the SI values of the each sample.

Sli= Wi $\times q i$

WQI $=\sum S I$,

Sli, qi and $n$ : the sub-index of ith parameter, rating based on the concentration of ith parameter and $n$ is the number of parameters respectively.

Considering the groundwater samples of PRM, 7\% of the total samples are within excellent category, $76 \%$ of the samples are within moderate quality, and 17\% of the samples are within bad quality. In SWM, 74\% of the samples are in the good category, $19 \%$ of the samples are in poor category, and the remaining are within very poor category. When comparing the samples of both NEM and POM to other two seasons $50 \%$ of samples are in the poor category, with a few samples falling into the extremely poor and unsuitable category (Table 6). These samples are unfit for drinking purpose. Spatial distributions of WQI (Fig 4) for four seasons show predominance of excellent and good category water in the study area. The water quality index of PRM and NEM ranges from 42.16 (Kulukanatham) to 375.06 (Karapadi) respectively. A small patch of un-suitable category of water is noted in the north-eastern part of the study field during POM (Fig 5) may be due to ion leaching, over-exploitation, direct discharge of domestic and industrial effluents along the Vellar River.

\section{Electrical Conductivity vs Water Quality Index}

The relationship between WQI and EC is plotted (Fig 4). It is interesting to note that EC values increases with the increase of WQI which may be an indication of water pollution. There are two groups of the samples represented in the plot (Fig 4). One with high EC and high WQI and the other with low EC and low WQI. But in general, there exist a linear relationship between EC and WQI, reflecting the fact that they are directly related and the increase is mainly due to the anthropogenic influence (Thivya et al., 2013). 


\section{Gibbs plot for evaluation of geochemical control on groundwater}

The samples of all four different sampling periods fall within weathering and evaporation zone. However, the samples of cation plot show a dominance of weathering than that anion plot (Fig 6) Majority of the samples regardless of season fall outside of the plot which signifies the anthropogenic impact in the study area. The concept of the diagram is based on the TDS and ion ratios as mentioned in the figure 6, but however samples which are outside of the plot and the samples which are having higher TDS but are within the evaporation zone may also be due to anthropogenic sources other than the natural sources like rain, weathering, and evaporation. Thus, it can be inferred that evaporation and wethering plays a significant role in variation of groundwater chemistry of the region nalong with anthropogenic activities.

\section{Geochemical classification}

Majority of the samples are within the field 1 to 4 and a few representations of samples are also noted in field 5 irrespective of seasons (Fig 7). The samples which are within Field 2 are of the $\mathrm{Na}-\mathrm{Cl}$ type, Field 3 of $\mathrm{Ca}-\mathrm{Na}-\mathrm{HCO}_{3}$ type and Field 4 of $\mathrm{Ca}-\mathrm{Mg}-\mathrm{Cl}$ type, and Field 1 of $\mathrm{Ca}-\mathrm{HCO}_{3}$ and Field 5 of $\mathrm{Ca}-\mathrm{Cl}$ type (Fig 7). The $\mathrm{Na}-\mathrm{Cl}$ type dominates because ions are removed from the solution by adsorption or precipitation (Chidambaram et al., 2007). (Thilagavathi and colleagues, 2012, Vetrimurugan 2013). The migration of samples from the mixed $\mathrm{Ca}-\mathrm{Mg}-\mathrm{Cl}$ facies to the $\mathrm{Na}-\mathrm{Cl}$ facies could be attributable to seawater effect in the sedimentary area, as well as the extended residence period of shallow groundwater (Prasanna et al., 2012), where $\mathrm{Na}$ exceeds $\mathrm{Ca}$ and $\mathrm{Mg}, \mathrm{Cl}$ exceeds $\mathrm{HCO} 3$ and SO4 (Prasanna et al., 2012). (Prasanna et al. 2008). A saline environment is indicated by the presence of $\mathrm{Na}-\mathrm{Cl}$ water in the discharge zone (Prasanna et al., 2009). The high $\mathrm{Cl}$ concentration could be the result of saline soil residues seeping into the groundwater system, which is frequent in dry and semi-arid areas (Zaheeruddin and Khurshid 2004).

The evolution of groundwater chemistry represented by the samples in field 1,4 and 5 are $\mathrm{Ca}-\mathrm{HCO}_{3}$, Ca$\mathrm{Mg}-\mathrm{Cl}$, and $\mathrm{Ca}-\mathrm{Cl}$ type. The $\mathrm{Ca}-\mathrm{HCO}_{3}$ facies represent the recharge process of the region (Thilagavathi et al., 2011). Anions are considered to change from $\mathrm{HCO} 3$ to $\mathrm{Cl}$ from recharge to discharge due to ion dissolution in the pathway or precipitation and removal of $\mathrm{HCO} 3$ from the aqueous system (Tirumalesh et al., 2007). Most of the samples fall into field 4, indicating Ca-Mg-Cl type (Fig 7), with a few samples falling into $\mathrm{Ca}-\mathrm{HCO} 3$ and $\mathrm{Na}-\mathrm{Cl}$ types, indicating secondary precipitation action. In general, alkali exceeds alkali earth, indicating that strong acid controls the chemistry of water.

\section{Correlation Matrix}

In PRM season, good correlation observed between $\mathrm{Mg}-\mathrm{Cl}, \mathrm{Mg}-\mathrm{EC}, \mathrm{Mg}-\mathrm{TDS}, \mathrm{Na}-\mathrm{Cl}, \mathrm{Na}-\mathrm{HCO}_{3}, \mathrm{Cl}-\mathrm{TDS}$, $\mathrm{HCO}_{3}-\mathrm{SO}_{4}, \mathrm{HCO}_{3}-\mathrm{EC}, \mathrm{HCO}_{3}$-TDS, $\mathrm{SO}_{4}$-EC, $\mathrm{SO}_{4}$-TDS and EC-TDS (Table 7). All the variables have a negative and poor correlation with $\mathrm{pH}$ (Table 7), which can be explained by acidic media's higher aggressiveness against soil and host rocks, which increases the concentrations of the other ions. Due to the high agricultural and industrial activity i.e., fertilizers and/ or industrial wastes are Predominant in the region, 
which release all these ions into the aquifer increasing its concentration. TDS and EC $(R=0.991)$ have a strong positive correlation, indicating the impact of all dissolved constituent ions in the water increase. In SWM, good correlation exists between Ca-Mg, Na, Cl, SO ${ }_{4} \mathrm{EC}$, TDS, Mg-Na, Cl, SO${ }_{4}, \mathrm{EC}, \mathrm{TDS}, \mathrm{Na}-\mathrm{Cl}, \mathrm{SO}_{4}, \mathrm{EC}$, TDS, $\mathrm{Cl}_{-} \mathrm{HCO}_{3}, \mathrm{SO}_{4}, \mathrm{EC}, \mathrm{TDS}, \mathrm{HCO}_{3}-\mathrm{EC}, \mathrm{TDS}, \mathrm{SO}_{4}-\mathrm{EC}$, TDS, EC-TDS indicating the dominance of weathering and leaching processes. Cl-has strong associations with $\mathrm{Na}, \mathrm{Ca}, \mathrm{Mg}$, and $\mathrm{K}$, indicating the predominance of secondary salt leaching. $\mathrm{HCO}_{3}$-has a strong correlation with $\mathrm{Ca}, \mathrm{Mg}, \mathrm{Na}$, and $\mathrm{K}$, suggesting the presence of dissolved solids due to chemical weathering. The high correlation with Na may be due to the higher $\mathrm{Na}$ content in the source material, which causes water to become alkaline. $\mathrm{PO}_{4}{ }^{3}$ shows significant correlation with $\mathrm{K}$ and $\mathrm{SO}_{4}{ }^{2}$ indicates fertilizer impact from agricultural practices. In NEM, good correlation exists between Ca-Mg, $\mathrm{Na}, \mathrm{Cl}, \mathrm{SO}_{4}, \mathrm{EC}$, TDS, Mg-Na, Cl, SO $\mathrm{S}_{4}, \mathrm{EC}$, TDS, Na-K, Cl, SO $\mathrm{S}_{4}, \mathrm{EC}, \mathrm{TDS}, \mathrm{Cl}$ $\mathrm{SO}_{4}, \mathrm{EC}, \mathrm{TDS}, \mathrm{SO}_{4}-\mathrm{EC}$, TDS, EC-TDS (Table 7). $\mathrm{HCO}_{3}, \mathrm{Cl}, \mathrm{Na}, \mathrm{Ca}$, and $\mathrm{Mg}$ are the main ions with strong to moderate correlation with other ions in almost all seasons. This could be due to secondary salts leaching from fissures or hydrophobic areas of the formations (Chidambaram et al., 2009).In POM good

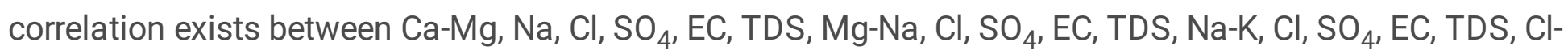
$\mathrm{SO}_{4}, \mathrm{EC}, \mathrm{TDS}, \mathrm{SO}_{4}-\mathrm{EC}$, TDS, EC-TDS (Table 7). Cl have a strong relationship with $\mathrm{Ca}, \mathrm{Mg}$, and $\mathrm{Na}$, suggesting that chemical weathering and secondary salt leaching are prevalent during this season (Prasanna 2008). The lack of correlation between $\mathrm{H}_{4} \mathrm{SiO}_{4}$ and other ions suggests that silica has a lesser influence during this season. The lack of a positive association between $\mathrm{PO}_{4}{ }^{3}$ and $\mathrm{K}$ signifies the influence of anthropogenic activities basically the fertilisers applied in the cultivated land. Cl-has a strong positive correlation with $\mathrm{Mg}, \mathrm{Ca}$, and $\mathrm{Na}$, suggesting secondary salt leaching. Thus, the main factor which contributes to the variation in groundwater chemistry of this region is may be weathering, salt leaching and anthropogenic activities.

\section{Factor Analysis}

In PRM 4 factors were extracted with 68.09\% (Table 8) of Total Data Variance (TDV). Factor 1 have a strong loading (TDV: $27.59 \%$ ) of $\mathrm{EC}, \mathrm{TDS}, \mathrm{SO}_{4}{ }^{2-}$ and with moderate loading of $\mathrm{Mg}$ and $\mathrm{HCO}_{3}$. Factor 1 's ion association indicates weathering mechanisms as well as secondary salt leaching along the fracture (Chidambaram, 2000). The presence of $\mathrm{Ca}$ and $\mathrm{Mg}$ ions indicates natural recharge and rock water interaction process (Olobaniyi, 2006). The moderate loading of factor 2 with $\mathrm{K}, \mathrm{PO}_{4}$ and $\mathrm{HCO}_{3}$ (TDV: $15.96 \%$ ), indicates anthropogenic activities like application of fertilizers in agricultural field, and dissolution of $\mathrm{HCO}_{3}$ ion during weathering process. Factor 3 with a TDV of $13.78 \%$ represents strong loading of $\mathrm{Na}$ and $\mathrm{Cl}$ indicating anthropogenic influence. A strong loading of $\mathrm{NO}_{3}$ represented in Factor 4 (TDV: $10.77 \%$ ), indicating source from fertilizers applied in the agricultural land.

Four factors were extracted with $74.49 \%$ of TDV (Table 8). $\mathrm{Ca}, \mathrm{Mg}, \mathrm{Na}, \mathrm{Cl}, \mathrm{HCO}_{3}, \mathrm{SO}_{4}{ }^{2}$, EC, TDS shows a strong positive loading for factor 1 (TDV: $43.47 \%$ ). This association is distinguished by the predominance of secondary salt dissolution into groundwater during the monsoon. Factor 2 (TDV: 11.42 \%) shows moderate loading of $\mathrm{K}_{1} \mathrm{NO}_{3}, \mathrm{PO}_{4}{ }^{3}$, and $\mathrm{SO}_{4}{ }^{2}$, which suggests anthropogenic impacts from 
agricultural activities such as fertilizers (Vengosh et al.1995). There is a negative loading of $\mathrm{Mg}$ and $\mathrm{pH}$ is noted in Factor 3 (TDV: $10.13 \%$ ). In Factor 4 (TDV: 9.47\%) strong and weak loading of $\mathrm{H}_{4} \mathrm{SiO}_{4}$ and $\mathrm{NO}_{3}$ is noted indicating anthropogenic influence and leaching of silicate ions into the aquifers.

The NEM have four major factors that explained $71 \%$ of the total variance. The Factor 1 (TDV: $42.65 \%$ ) with positive loadings of $\mathrm{Ca}, \mathrm{Mg}, \mathrm{Na}, \mathrm{Cl}, \mathrm{SO}_{4}{ }^{2}$, and $\mathrm{EC}$, suggesting secondary salt leaching into the aquifer (Table 8). Other two factors like factor 2 and 3 does not show any strong loadings of ions. However, the strong positive loadings of $\mathrm{H}_{4} \mathrm{SiO}_{4}$ in Factor 4 (TDV: $10.76 \%$ ) suggests the influence of silicate weathering,

During POM, four factors were extracted with (Table 8) $76.56 \%$ of TDV. Factor 1 show $23.5 \%$ of TDV. The positive loading of the $\mathrm{Ca}^{2+}, \mathrm{Mg}^{2+}, \mathrm{Na}^{+}, \mathrm{Cl}^{-}, \mathrm{HCO}_{3}{ }^{-}$, and $\mathrm{EC}$ in Factor 1 is attributed to the secondary leaching of salts. Factor 2 with of $12.49 \%$ of TDV shows positive loading of $\mathrm{K}$ and $\mathrm{PO}_{4}{ }^{3}$ is mainly due to the anthropogenic stress in groundwater. Factor 3 (TDV: 10.89\%) does not show any significant loadings of ions. Factor 4 (TDV: $10.06 \%$ ) represents strong positive loading of $\mathrm{HCO}_{3}{ }^{-}$. indicating water-/rock interaction and also this factor has a moderate loading of $\mathrm{H}_{4} \mathrm{SiO}_{4}$ indicating the leaching of silicate ions into the (Prasanna 2010).

\section{Conclusion}

Almost all the chemical and physical parameters are exceeding the permissible limit. However, most of the individual samples are within the limit of WHO standard. The water quality of this area has been classified into 5 different types based upon their water quality index value as excellent, good, poor, very poor to unsuitable category. Gibb's plot confirms the dominance of weathering and evaporation process and the representation of samples outside of the plot signifying the predominance of anthropogenic activities. There is existence of five different water types observed in the groundwater are $\mathrm{Na}-\mathrm{Cl}$ type, Ca$\mathrm{Na}-\mathrm{HCO}_{3}, \mathrm{Ca}-\mathrm{Mg}-\mathrm{Cl}$ type, and $\mathrm{Ca}-\mathrm{HCO}_{3}$ and $\mathrm{Ca}-\mathrm{Cl}$ type but maximum representations are within field 1 to 4 signifying the leaching of ions from the underlying sedimentary rock types through weathering and dominance of anthropogenic activities. The groundwater in proposed region is experiencing the impact of geochemical processes like weathering and ion exchange apart from anthropogenic stress which controls water chemistry. The chemistry of ions like calcium, magnesium, sodium and potassium is controlled by the process of weathering of minerals in aquifer matrix. The processes like water-rock interaction and agricultural activities significantly control the hydrogeochemistry of the groundwater in the region. $\mathrm{Cl}$ is dominant due to anthropogenic impact (human sources). Most of the samples are within good and poor category which signifies that the water quality is gradually deteriorating in this region and can be utilized for agricultural purpose directly without any treatment and drinking purpose after treatment. Thus, the controlling factors which impact the water composition of this area has been evaluated through various geochemical diagrams and analysis for to derive a suitable criterion for the management of the resource in near future. 


\section{Declarations}

\section{Data availability statement}

Data will be made available on request

\section{References}

1. Adithya VS, Chidambaram S, Keesari T, Mohokar HV, Prasanna MV. Occurrence of Uranium in Groundwater Along the Lithological Contacts in Central Tamilnadu, India: An Isotope Hydrogeochemical Perspective. Exposure and Health; 2019 11, 277-290. doi:10.1007/s12403-0170269-3.

2. Adithya VS, Chidambaram S, Keesari T, Thivya C, Thilagavathi R, Senapathi,V, Viswanathan PM, Samayamanthu DR. Seasonal changes in groundwater quality deterioration and chemometric analysis of pollution source identification in South India. Environmental Science and Pollution Research 27, 20037-20054; 2020 doi:10.1007/s11356-020-08258-6.

3. Adithya VS, Chidambaram S, Tirumalesh K, Thivya C, Thilagavathi R, Prasanna MV,. Assessment of sources for higher Uranium concentration in ground waters of the Central Tamilnadu, India. IOP Conference Series: Materials Science and Engineering 121, 012009; 2016 doi:10.1088/1757899x/121/1/012009.

4. Anandhan P. Hydrogeochemical studies in and around Neyveli mining region, Tamilnadu, India. Ph.D Thesis, Department of Earth Sciences, Annamalai University, 189p; 2005.

5. Atwia MG, Hassan AA, Ibrahim SA. Hydrogeology, Log Analysis, and Hydrochemistry of Unconsolidated Aquifers South of El-Sadat City, Egypt. Hydrogeology Journal 5, 27-38; 1997. doi:10.1007/s100400050108.

6. Carroll. Rain water is a chemical agent of geological process a review US Geological survey water supply paper; 1962 1535-G.

7. CGWB. Report of the group for suggesting new and alternate methods of ground water resources assessment, Central Ground Water Board, Ministry of Water Resources, Govt. of India, Faridabad; 2009. 26p.

8. Cherry NM, Burgess GL, Turner S, McDonald JC. Cohort study of Staffordshire pottery workers :(II) Nested case referent analysis of lung cancer.The Annals of Occupational Hygiene; 1997. 41, 408411.

9. Cherry NM, Burgess GL, Turner S, McDonald JC. Crystalline silica and risk of lung cancer in the potteries. Occupational and environmental medicine; 1998 55(11), 779-785.

10. Chidambaram S. Hydrogeochemical studies of groundwater in Periyar district, Tamilnadu, India. Unpublished Ph. D thesis, Department of Geology, Annamalai University; 2000.

11. Chidambaram S, Anandhan P, Prasanna MV, Ramanathan AL, Srinivasamoorthy K, Senthil Kumar G. Hydrogeochemical Modelling for Groundwater in Neyveli Aquifer, Tamil Nadu, India, Using PHREEQC: 
A Case Study. Natural Resources Research; 2012. 21, 311-324. doi:10.1007/s11053-012-9180-6.

12. Chidambaram S, Bala Krishna Prasad M, Manivannan R, Karmegam U, Singaraja C, Anandhan $P$, Prasanna MV, Manikandan S. Environmental hydrogeochemistry and genesis of fluoride in ground waters of Dindigul district, Tamil Nadu (India). Environ Earth Sci; 2013. 68:333-342.

13. Chidambaram S, Pethaperumal S, Thilagavathi R, Dhanu Radha V, Thivya C, Prasanna MV, Tirumalesh K, Panda BR Seasonal Variations of Groundwater Geochemistry in Coastal Aquifers, Pondicherry Region, South India. Coastal Zone Management; 2019. 361-380. doi:10.1016/b978-012-814350-6.00015-x.

14. Chidambaram S, Ramanathan AL, Anandhan P, Srinivasamoorthy K, Vasudevan S, Prasanna MV. A study of the coastal groundwaters from Puduchattiram to Coleroon Tamilnadu, India. Int J Ecol Environ Sci; 2005. 299-306 vol 31.

15. Chidambaram S, Ramanathan AL, Prasanna MV, Anandhan P, Srinivasamoorthy K, Vasudevan S. Identification of hydrogeochemically active regimes in groundwaters of Erode district, TamilnaduA statistical approach. Asian Journal of water, Environment and pollution; 2008. vol. 5, no. 3, pp. 93102.

16. Chidambaram S, Ramanathan AL, Prasanna MV, Karmegam U, Dheivanayagi V, Ramesh R, Johnsonbabu G, Premchander B, Manikandan S. Study on the hydrogeochemical characteristics in groundwater, post- and pre-tsunami scenario, from Portnova to Pumpuhar, southeast coast of India. Environmental Monitoring and Assessment; 2009. 169, 553-568. doi:10.1007/s10661-009-1196-y.

17. Chidambaram S, Rashid T, Al-Qallaf H, Hadi K, Bhandary H. Paleoclimatic investigations using isotopic signatures of the Late Pleistocene-Holocene groundwater of the stratified aquifers in Kuwait. Journal of Hydrology; 2020. 588, 125111. doi:10.1016/j.jhydrol.2020.12511.

18. Chidambaram S, Vijayakumar V, Srinivasamoorthy K, Anandhan P, Prasanna MV, Vasudevan S. A study on variation in ionic composition of aqueous system in different lithounits around Perambalur region, Tamil nadu. Journal-Geological Society Of India; 2007. V 70(6) pp 1061 - 1069.

19. Collin AG. Geochemistry of oil field waters. Amsterdam, Elsevier Scientific Pub. Company; 1975. 496p.

20. Devaraj N, Chidambaram S, Panda B, Thivya C, Thilagavathi R, Ganesh N. Geo-electrical approach to determine the lithological contact and groundwater quality along the KT boundary of Tamilnadu, India. Modeling Earth Systems and Environment; 2018. 4, 269-279. doi:10.1007/s40808-018-04242.

21. Devaraj N, Chidambaram S, Panda, B, Thivya C, Tirumalesh K, Thilagavathi R. Determination of Anthropogenic Sources in the Groundwater Chemistry Along KT Boundary of South India. Emerging Issues in the Water Environment during Anthropocene; 2019. 127-142. doi:10.1007/978-981-329771-5_7.

22. Devaraj N, Chidambaram S, Vasudevan U, Pradeep K, Nepolian M, Prasanna MV, Adithya VS, Thilagavathi R, Thivya C, Panda B. Determination of the major geochemical processes of 
groundwater along the Cretaceous-Tertiary boundary of Trichinopoly, Tamilnadu, India. Acta Geochimica; 2020. 39, 760-781. doi:10.1007/s11631-020-00399-2.

23. Devaraj N, Panda B, Chidambaram S, Prasanna MV, Dhiraj Kr Singh, Ramanathan AL, Sahoo, S.K. Spatio-temporal variations of Uranium in groundwater: Implication to the environment and human health. Science of The Total Environment; 2021. 775, 145787. doi:10.1016/j.scitotenv.2021.145787.

24. Dobrzyński D. Silica origin and solubility in groundwater from the weathered zone of sedimentary rocks of the Intra-Sudetic Basin, SW Poland. ActaGeologicaPolonica; 2005. 55(4), 445-462.

25. Durov SA. Natural water sand graphic representation of their composition DOK. Akad Nauk SSSR; 1948. v.59, pp.87 - 90.

26. Fisher RS, Mullican III, W.F. Hydrochemical Evolution of Sodium-Sulfate and Sodium-Chloride Groundwater Beneath the Northern Chihuahuan Desert, Trans-Pecos, Texas, USA. Hydrogeology Journal; 1997. 5, 4-16. doi:10.1007/s100400050102.

27. Freeze AR, Cherry JA. Groundwater, Prentice - Hall, Inc Englewood cliffs, New Jersey; 1979. 604p.

28. Gibbs RJ. Mechanisms controlling world's water chemistry, Science; 1970.170, pp 1088-1090.

29. Handa BK. Modified Hill-piper diagram for presentation of water analysis data.Curr, Sci; 1965. 34:131-314.

30. Johnson JH. Hydrochemistry in groundwater exploration-Groundwater Symposisium Bulawayo; 1975.

31. Karmegam U, Chidambaram S, Prasanna MV, Sasidhar P, Manikandan S, Johnsonbabu G, Dheivanayaki V, Paramaguru P, Manivannan R, Srinivasamoorthy K, Anandhan P. A study on the mixing proportion in groundwater samples by using Piper diagram and Phreeqc model, Chin.J.Geochem; 2011. Vol. 30:490-495.

32. Lavitt N, Acworth RI, Jankowski J. Vertical Hydrochemical Zonation in a Coastal Section of the Botany Sands Aquifer, Sydney, Australia. Hydrogeology Journal; 1997. 5, 64-74. doi:10.1007/s100400050117.

33. Nepolian M, Chidambaram S, Thivya C, Thilagavathi R, Rakesh Roshan Gantayat, Parama Guru P, Pradeep K. A study on the spatial analysis of dissolved silica in groundwater of villupuram district of tamil nadu. Int. J. of Geol. \& Earth Sci; 2016. ISSN 2395-647X.

34. Olobaniyi SB, Owoyemi FB. Characterization by factor analysis of the chemical facies of groundwater in the deltaic plain sands aquifer of Warri, western Niger delta, Nigeria. African Journal of Science and Technology 7; 2006. doi:10.4314/ajst.v7i1.55201.

35. Panda B, Chidambaram S, Ganesh N, Adithya VS, Pradeep K, Vasudevan U, Ramanathan AL, Ranjan $\mathrm{S}$, Prasanna MV, Paramaguru K, A study on mountain front recharge by using integrated techniques in the hard rock aquifers of southern India. Environment, Development and Sustainability. 2018. 20, 2243-2259. doi:10.1007/s10668-017-9987-8.

36. Panda B, Chidambaram S, Ganesh N, Adithya VS, Prasanna MV, Pradeep K, Vasudevan U. A hydrochemical approach to estimate mountain front recharge in an aquifer system in Tamilnadu, India. Acta Geochimica; 2018. 37, 465-488. doi:10.1007/s11631-017-0229-4. 
37. Panda B, Chidambaram S, Malakar A. Survival of SARS-COV-2 in untreated and treated wastewatera review. Environmental Resilience and Transformation in Times of COVID-19; 2021 89-94. doi:10.1016/b978-0-323-85512-9.00009-7.

38. Panda B, Chidambaram S, Thilagavathi R, Ganesh N, Prasanna MV, Vasudevan U. Source governed trace metal anomalies in groundwater of foothill aquifer and its health effect. Applied Water Science; 2020. 10. doi:10.1007/s13201-020-01253-9.

39. Panda B, Chidambaram S, Thilagavathi R, Thivya C, Ganesh N, Devraj N. Geochemical signatures of groundwater along mountain front and riparian zone of Courtallam, Tamil Nadu. Groundwater for Sustainable Development; 2018. doi:10.1016/j.gsd.2017.10.003.

40. Piper AM. A graphic procedure in the geochemical interpretation of water analysis. Trans Amer Geophys union; 1944. v.25, pp.914 - 923.

41. Prasanna MV, Chidambaram S, Pethaperumal S, Srinivasamoorthy K, Peter AJ, Anandhan P, Vasanthavigar M. Integrated geophysical and chemical study in the lower subbasin of Gadilam River, Tamilnadu, India. Environmental Geosciences; 2008. 15, 145-152. doi:10.1306/eg.11080707015.

42. Prasanna, MV, Chidambaram S, Shahul Hameed A, Srinivasamoorthy K. Study of evaluation of groundwater in Gadilam Basin using hydrogeochemical and isotope data. Environmental monitoring and assessment; 2009. DOI 10.1007/s 10661-009-1092-5.

43. Prasanna MV, Praveena SM, Chidambaram S, Nagarajan R, Elayaraja A. Evaluation of water quality pollution indices for heavy metal contamination monitoring: a case study from Curtin Lake, Miri City, East Malaysia. Environmental Earth Sciences; 2012. 67, 1987-2001. doi:10.1007/s12665-012-16396.

44. Ramanathan AL, Subramanian V. Present Status of Asbestos Mining and Related Health Problems in India. A Survey. Industrial health; 2001. 39, 309-315. doi:10.2486/indhealth.39.309.

45. Ranjana UK, Naverathna MPC. River sand mining in southern Sri-Lanka and its effect on environment. In: 11th International River symposium on "A Future of extremes" Brisbane, Australia; 2011.

46. Stiff HA and Jr. The interpretation of chemical water analysis by means of patterns: Journal of Petroleum Technology; 1951. v. 3. no. 10, p. 15-17.

47. Thilagavathi G, Tamilenthi S, Ramu C, Baskaran R. Application of GIS in Flood Hazard Zonation Studies in Papanasam Taluk, Thanjavur District, Tamilnadu. Adv. Appl. Sci. Res; 2011. 2 (3):574-585.

48. Thilagavathi R, Chidambaram S, Pethaperumal S, Thivya C, Rao MS, Tirumalesh K, Prasanna MV, An attempt to understand the behavior of dissolved organic carbon in coastal aquifers of Pondicherry region, South India. Environmental Earth Sciences; 2016. 75. doi:10.1007/s12665-015-4833-5.

49. Thilagavathi R, Chidambaram S, Prasanna MV, Thivya C, Singaraja C. A study on groundwater geochemistry and water quality in layered aquifers system of Pondicherry region, southeast India. Applied Water Science; 2012. doi:10.1007/s13201-012-0045-2.

50. Thilagavathi R, Chidambaram, S, Thivya C, Prasanna MV, Keesari T, Pethaperumal S. Assessment of groundwater chemistry in layered coastal aquifers using multivariate statistical analysis. 
Sustainable Water Resources Management; 2018. doi:10.1007/s40899-017-0078-7.

51. Thivya C, Chidambaram S, Thilagavathi R, Nepolian M, VS. Evaluation of drinking water quality index (DWQI) and its seasonal variations in hard rock aquifers of Madurai district, Tamilnadu. International Journal of Advanced Geosciences 2; 2014. doi:10.14419/ijag.v2i2.2294.

52. Thivya C, Chidambaram S, Thilagavathi R, Prasanna MV, Singaraja C, Nepolian M, Sundararajan M. Identification of the geochemical processes in groundwater by factor analysis in hard rock aquifers of Madurai District, South India. Arabian Journal of Geosciences; 2013. 7, 3767-3777. doi:10.1007/s12517-013-1065-4.

53. Thivya C, Sabarathinam C, Devaraj N, Rajendiran T, Banajarani Panda, BR, Keesari T, Mohan Viswanathan P, Utharapathi V, Alagappan R, Geochemical (process based) characterization of groundwater along the KT boundary of South India. Geochemistry; 2019. doi:10.1016/j.geoch.2018.11.005.

54. Tirumalesh K, Shivanna K, Noble J, Narayan KK, Xavier KT. Nuclear techniques to investigate source and origin of groundwater pollutants and their flow path at Indian Rare Earths Ltd., Cochin, Kerala. Journal of Radioanalytical and Nuclear Chemistry; 2007. doi:10.1007/s10967-007-1116-y.

55. Vasanthavigar M, Srinivasamoorthy K, Vijayaragavan K, Rajiv Ganthi R, Chidambaram S, Anandhan P, Manivannan R, Vasudevan S. Application of water quality index for groundwater quality assessment: Thirumanimuttar sub-basin, Tamilnadu, India. Environmental Monitoring and Assessment; 2010. 171, 595-609. doi:10.1007/s10661-009-1302-1.

56. Vasudevan U, Ganesh N, Chidambaram S, Banajarani Panda, Nepolian M, Devaraj N, Pradeep K, Paramaguru P. Spatial interpolation techniques for the determination of utility of groundwater in Perambalur district, Tamilnadu, India; 2017. 330-340. Vol 39.Int J Appl Res.

57. Vasudevan U, Gantayat RR, Chidambaram S, Prasanna MV, Venkatramanan S, Devaraj N, Nepolian M, Ganesh N. Microbial contamination and its associations with major ions in shallow groundwater along coastal Tamil Nadu. Environmental Geochemistry and Health; 2020. 43, 1069-1088. doi:10.1007/s10653-020-00712-1.

58. Vengosh A, Keren R. Chemical modifications of groundwater contaminated by recharge of treated sewage effluent. Journal of Contaminant Hydrology; 1995. 23, 347-360. doi:10.1016/01697722(96)00019-8.

59. Vetrimurugan E, .Elango L, Rajmohan N. Sources of contaminants and groundwater quality in the coastal part of a river delta. Int. J. Environ. Sci. Technol; 2013.10:473-486 DOI 10.1007/s13762-0120138-3.

60. Vetrimurugan E, Elango, L, Groundwater Chemistry and Quality in an Intensively Cultivated River Delta. Water Qual Expo Health; 2014. DOI 10.1007/s12403-014-0133-7.

61. Vetrimurugan Elumalai, Vhonani G, Nethononda V, Manivannan N, Rajmohan Peiyue Li, L. Elango. Groundwater quality assessment and application of multivariate statistical analysis in Luvuvhu catchment, Limpopo, South Africa. ournal of African Earth Sciences; 2020. https://doi.org/10.1016/j.jafrearsci.2020.103967. 
62. Vijayakumar V, Krishnakumar S, Vasudevan S. An Environmental Quality Assessment on Groundwater Geochemistry in Western Part of Perambalur District, Tamilnadu, India. J. Env. Sci. Pollut. Res; 2016. 2(1) 54-56.

63. WHO. Guidelines for drinking-water quality (4th ed.). http://www.whqlibdoc.who.int/ publications; 2011./9789241548151_eng.pdf. Accessed 01/15/.

64. Zaheeruddin, Khurshid S. Aquifer Geometry and Hydrochemical Framework of the Shallow Alluvial Aquifers in the Western Part of the Yamuna River Basin, India. Water Quality Research Journal; 2004. 39, 129-139. doi:10.2166/wqrj.2004.020.

\section{Tables}

Table 1 Instrumental and volumetric methods used for chemical analysis of groundwater

\begin{tabular}{|lcc|}
\hline Parameter & Method and Instrument & Reference \\
\hline & & \\
\hline $\mathrm{Ca}^{2+}, \mathrm{Mg}^{2+}, \mathrm{HCO}_{3}, \mathrm{Cl}^{-}$ & Titrimetric method & APHA (1992) \\
$\mathrm{Na}^{+}, \mathrm{K}^{+}$ & Flame Photometer (Elico 378) & APHA (1992) \\
$\mathrm{SO}_{4}^{2-}, \mathrm{PO}_{4}{ }^{2-}, \mathrm{NO}_{3}, \mathrm{H}_{4} \mathrm{SiO}_{4}$ & $\mathrm{UV}-\mathrm{Spectrophotometer} \mathrm{(DR} \mathrm{6000,} \mathrm{HACH)}$ & APHA (1998) \\
$\mathrm{pH}_{3} \mathrm{EC}$ & Thermo Orion & APHA (1992) \\
\hline
\end{tabular}

Table 2: Maximum, Minimum and Average of physico chemical parameters for four different seasons in comparison with WHO (2011) standard (All the units are in milligrams per liter $(\mathrm{mg} / \mathrm{L})$ except $\mathrm{EC}-\mu \mathrm{S} / \mathrm{cm})$

\begin{tabular}{|c|c|c|c|c|c|c|c|c|c|c|c|c|c|}
\hline \multirow{2}{*}{$\begin{array}{l}\text { Season } \\
\text { Parameters }\end{array}$} & \multicolumn{3}{|c|}{$\begin{array}{c}\text { Pre-monsoon } \\
\text { (PRM) }\end{array}$} & \multicolumn{3}{|c|}{$\begin{array}{c}\text { North east monsoon } \\
\text { (NEM) }\end{array}$} & \multicolumn{3}{|c|}{$\begin{array}{c}\text { South west monsoon } \\
\text { (SWM) }\end{array}$} & \multicolumn{3}{|c|}{$\begin{array}{c}\text { Post-monsoon } \\
\text { (POM) }\end{array}$} & \multirow{2}{*}{$\begin{array}{l}\text { WHO } \\
\text { (2011) }\end{array}$} \\
\hline & Max & Min & Avg & Max & Min & Avg & Max & Min & Avg & Max & Min & Avg & \\
\hline $\mathrm{Ca}$ & 156 & 12 & 60.37 & 568 & 20 & 90.90 & 303.67 & 26.25 & 76.32 & 436 & 24 & 83.52 & 75 \\
\hline Mg & 76.80 & 7.20 & 32.14 & 191 & 4.80 & 30.20 & 137.64 & 10.26 & 31.89 & 166.30 & 9.50 & 31.23 & 50 \\
\hline $\mathrm{Na}$ & 606 & 6.40 & 85.12 & 577 & 7.20 & 220.35 & 522.36 & 23.65 & 152.79 & 491 & 12.65 & 186.55 & 200 \\
\hline $\mathbf{K}$ & 48.10 & 0.10 & 5.27 & 128 & 0.10 & 39.78 & 66.45 & 2.26 & 23.85 & 97.70 & 0.15 & 31.15 & 12 \\
\hline $\mathrm{Cl}$ & 771.04 & 17.73 & 180.18 & 1700 & 35.45 & 256.16 & 958.54 & 52.34 & 218.78 & 1331.97 & 59.82 & 237.16 & 250 \\
\hline $\mathrm{HCO}_{3}$ & 420 & 84 & 231.05 & 536.80 & 122 & 302.68 & 452.86 & 111.00 & 267.20 & 497.10 & 121.65 & 284.77 & 500 \\
\hline $\mathrm{NO}_{3}$ & 180.72 & 0.87 & 46.40 & 107.05 & 12.53 & 46.47 & 103.24 & 16.00 & 47.08 & 87.39 & 15.47 & 46.45 & 45 \\
\hline $\mathrm{PO}_{4}$ & 0.61 & $\mathrm{BDL}$ & 0.04 & 2.66 & 0.01 & 0.07 & 1.89 & 0.01 & 0.07 & 2.15 & 0.01 & 0.06 & NG \\
\hline $\mathrm{SO}_{4}$ & 40 & 0.36 & 2.92 & 16.30 & 0.36 & 1.58 & 27.16 & 0.49 & 3.01 & 22.02 & 0.37 & 1.91 & 250 \\
\hline $\mathrm{H}_{4} \mathrm{SiO}_{4}$ & 280 & 10 & 120.48 & 261 & 21.80 & 176.12 & 251.36 & 11.35 & 144.64 & 238.25 & 27.70 & 162.21 & NG \\
\hline TDS & 2550 & 181 & 642.83 & 3900 & 358 & 919 & 3219 & 354.00 & 780.17 & 3562.50 & 407.75 & 849.96 & 500 \\
\hline EC & 9970 & 341 & 1834.83 & 15170 & 905 & 2902.74 & 12559 & 825.00 & 2366.43 & 13870 & 911 & 2635.76 & 1500 \\
\hline pH & 8.38 & 6.70 & 7.36 & 7.22 & 6.21 & 6.55 & 7.79 & 6.55 & 6.98 & 7.32 & 6.43 & 6.75 & $6.5-8.5$ \\
\hline
\end{tabular}

Table 3: EC classification displaying number of samples in each class for Pre-Monsoon, South West Monsoon, North East Monsoon and Post Monsoon 


\begin{tabular}{|l|c|c|c|c|}
\hline \multirow{2}{*}{$\begin{array}{c}\text { Classification wrt to EC } \\
(\boldsymbol{\mu} \mathbf{\mu} / \mathbf{c m}) \text { value }\end{array}$} & \multicolumn{4}{|c|}{ No. of Samples (N=168) } \\
\cline { 2 - 5 } & PRM & SWM & NEM & POM \\
\hline$<1500$ (Fresh Water) & 22 & 12 & 09 & 07 \\
\hline $1500-3000$ (Brackish Water) & 17 & 23 & 26 & 29 \\
\hline$>3000$ (Saline Water) & 03 & 07 & 07 & 06 \\
\hline
\end{tabular}

Table 4: Water Quality Classification Based on TDS by Carroll (1962)

\begin{tabular}{|c|c|c|c|c|c|}
\hline TDS (ppm) & Water quality & \multicolumn{4}{|c|}{ No. of Samples } \\
\cline { 3 - 6 } & & PRM & SWM & NEM & POM \\
\hline $0-1000$ & Fresh water & 39 & 37 & 33 & 36 \\
\hline $1000-10,000$ & Brackish water & 3 & 5 & 9 & 6 \\
\hline $10,000-100,000$ & Salty water & 0 & 0 & 0 & 0 \\
\hline$>100,000$ & Brine & 0 & 0 & 0 & 0 \\
\hline
\end{tabular}

Table 5: Relative weight of chemical of physico-chemical parameters

\begin{tabular}{|l|c|c|c|c|c|c|c|c|c|}
\hline & \multicolumn{2}{|c|}{ PRM } & \multicolumn{2}{c|}{ SWM } & \multicolumn{2}{c|}{ NEM } & \multicolumn{2}{c|}{ POM } & \\
\hline Parameters & weight & $\begin{array}{l}\text { Relative } \\
\text { weight }\end{array}$ & weight & $\begin{array}{l}\text { Relative } \\
\text { weight }\end{array}$ & weight & $\begin{array}{l}\text { Relative } \\
\text { weight }\end{array}$ & weight & $\begin{array}{l}\text { Relative } \\
\text { weight }\end{array}$ & $\begin{array}{l}\text { WHO } \\
\mathbf{2 0 1 1}\end{array}$ \\
\hline $\mathrm{Ph}$ & 5 & 0.26 & 5 & 0.24 & 5 & 0.22 & 5 & 0.22 & $6.5-8.5$ \\
\hline $\mathrm{TDS}$ & 5 & 0.26 & 5 & 0.24 & 5 & 0.22 & 5 & 0.22 & 500 \\
\hline $\mathrm{Ca}$ & 1 & 0.05 & 2 & 0.10 & 3 & 0.13 & 2 & 0.09 & 75 \\
\hline $\mathrm{Mg}$ & 1 & 0.05 & 1 & 0.05 & 1 & 0.04 & 1 & 0.04 & 50 \\
\hline $\mathrm{HCO} 3$ & 1 & 0.05 & 1 & 0.05 & 1 & 0.04 & 1 & 0.04 & 500 \\
\hline $\mathrm{Cl}$ & 1 & 0.05 & 2 & 0.10 & 2 & 0.09 & 2 & 0.09 & 250 \\
\hline $\mathrm{Na}$ & 1 & 0.05 & 1 & 0.05 & 2 & 0.09 & 2 & 0.09 & 200 \\
\hline $\mathrm{K}$ & 1 & 0.05 & 1 & 0.05 & 1 & 0.04 & 2 & 0.09 & 12 \\
\hline $\mathrm{NO}$ & 1 & 0.05 & 1 & 0.05 & 1 & 0.04 & 1 & 0.04 & 45 \\
\hline $\mathrm{SO}$ & 1 & 0.05 & 1 & 0.05 & 1 & 0.04 & 1 & 0.04 & 250 \\
\hline & $\sum \boldsymbol{w i}=\mathbf{1 9}$ & $\sum \boldsymbol{W i}=\mathbf{l}$ & $\sum \boldsymbol{w i} \boldsymbol{i}=\mathbf{2 l}$ & $\sum \boldsymbol{W} \boldsymbol{i}=\mathbf{l}$ & $\sum \boldsymbol{w i} \boldsymbol{i}=\mathbf{2 3}$ & $\sum \boldsymbol{W i}=\mathbf{l}$ & $\sum \boldsymbol{w i}=\mathbf{2 3}$ & $\sum \boldsymbol{W i}=\mathbf{l}$ & \\
\hline
\end{tabular}

Table 6: Water quality classification based on their WQI values.

\begin{tabular}{|c|c|c|c|c|c|}
\hline Range & Category & PRM & SWM & NEM & POM \\
\hline$<50$ & Excellent & 3 & 0 & 1 & 0 \\
\hline $50-100$ & Good & 33 & 31 & 17 & 19 \\
\hline $100-200$ & Poor & 6 & 8 & 21 & 20 \\
\hline $200-300$ & Very Poor & 0 & 3 & 1 & 2 \\
\hline$>300$ & Unsuitable & 0 & 0 & 2 & 1 \\
\hline
\end{tabular}

Table 7: Correlation matrix for four season (PRM, POM, SWM and NEM) 


\begin{tabular}{|c|c|c|c|c|c|c|c|c|c|c|c|c|c|}
\hline PRM & $\mathrm{Ca}$ & Mg & $\mathrm{Na}$ & $\mathbf{K}$ & $\mathrm{Cl}$ & $\mathrm{HCO}_{3}$ & $\mathrm{NO}_{3}$ & $\mathrm{PO}_{4}$ & $\mathrm{SO}_{4}$ & $\mathrm{H}_{4} \mathrm{SiO}_{4}$ & pH & EC & TDS \\
\hline $\mathrm{Ca}$ & 1 & & & & & & & & & & & & \\
\hline Mg & 0.085 & 1 & & & & & & & & & & & \\
\hline $\mathbf{N a}$ & -0.153 & 0.28 & 1 & & & & & & & & & & \\
\hline $\mathbf{K}$ & -0.133 & -0.067 & 0.096 & 1 & & & & & & & & & \\
\hline Cl & 0.23 & 0.522 & 0.785 & 0.067 & 1 & & & & & & & & \\
\hline $\mathrm{HCO}_{3}$ & -0.048 & 0.4 & 0.568 & 0.328 & 0.364 & 1 & & & & & & & \\
\hline $\mathrm{NO}_{3}$ & 0.198 & -0.315 & -0.134 & -0.115 & -0.274 & -0.26 & 1 & & & & & & \\
\hline $\mathrm{PO}_{4}$ & 0.007 & 0.074 & 0.04 & 0.173 & 0.063 & 0.138 & -0.035 & 1 & & & & & \\
\hline $\mathrm{SO}_{4}$ & 0.042 & 0.491 & 0.348 & -0.057 & 0.21 & 0.501 & -0.048 & -0.064 & 1 & & & & \\
\hline $\mathrm{H}^{4} \mathrm{SiO}_{4}$ & 0.074 & 0.072 & 0.252 & 0.289 & 0.207 & 0.204 & 0.075 & 0.039 & 0.057 & 1 & & & \\
\hline pH & -0.165 & -0.063 & -0.014 & 0.188 & 0.091 & -0.204 & -0.32 & -0.043 & -0.175 & -0.123 & 1 & & \\
\hline EC & 0.181 & 0.587 & 0.534 & 0.002 & 0.464 & 0.624 & -0.092 & -0.028 & 0.931 & 0.187 & -0.164 & 1 & \\
\hline TDS & 0.187 & 0.587 & 0.595 & 0.061 & 0.53 & 0.666 & -0.093 & -0.018 & 0.885 & 0.227 & -0.152 & 0.991 & 1 \\
\hline \multicolumn{14}{|l|}{ SWM } \\
\hline $\mathrm{Ca}$ & 1 & & & & & & & & & & & & \\
\hline Mg & 0.789 & 1 & & & & & & & & & & & \\
\hline $\mathbf{N a}$ & 0.589 & 0.649 & 1 & & & & & & & & & & \\
\hline $\mathbf{K}$ & 0.096 & 0.276 & 0.513 & 1 & & & & & & & & & \\
\hline $\mathrm{Cl}$ & 0.768 & 0.785 & 0.844 & 0.439 & 1 & & & & & & & & \\
\hline $\mathrm{HCO}_{3}$ & 0.304 & 0.37 & 0.573 & 0.275 & 0.516 & 1 & & & & & & & \\
\hline $\mathrm{NO}_{3}$ & 0.148 & -0.109 & 0.111 & 0.09 & 0.012 & -0.004 & 1 & & & & & & \\
\hline $\mathrm{PO}_{4}$ & -0.044 & 0.036 & 0.099 & 0.214 & 0.029 & 0.139 & 0.205 & 1 & & & & & \\
\hline SO4 & 0.787 & 0.784 & 0.555 & 0.218 & 0.796 & 0.419 & -0.031 & -0.049 & 1 & & & & \\
\hline $\mathrm{H}_{4} \mathrm{SiO}_{4}$ & 0.123 & -0.019 & 0.078 & 0.076 & 0.129 & 0.174 & 0.203 & 0.068 & 0.004 & 1 & & & \\
\hline pH & -0.381 & -0.269 & 0.014 & 0.185 & -0.109 & -0.004 & -0.236 & -0.069 & -0.227 & -0.075 & 1 & & \\
\hline EC & 0.802 & 0.826 & 0.708 & 0.359 & 0.92 & 0.524 & 0.028 & -0.007 & 0.95 & 0.082 & -0.202 & 1 & \\
\hline TDS & 0.77 & 0.793 & 0.76 & 0.396 & 0.943 & 0.572 & 0.05 & -0.004 & 0.912 & 0.122 & -0.155 & 0.99 & 1 \\
\hline
\end{tabular}




\begin{tabular}{|c|c|c|c|c|c|c|c|c|c|c|c|c|c|}
\hline NEM & $\mathrm{Ca}$ & $\mathrm{Mg}$ & $\mathrm{Na}$ & $\mathbf{K}$ & $\mathrm{Cl}$ & $\mathrm{HCO}_{3}$ & $\mathrm{NO}_{3}$ & $\mathrm{PO}_{4}$ & $\mathrm{SO}_{4}$ & $\mathrm{H}_{4} \mathrm{SiO}_{4}$ & $\mathrm{pH}$ & EC & TDS \\
\hline $\mathrm{Ca}$ & 1 & & & & & & & & & & & & \\
\hline Mg & 0.89 & 1 & & & & & & & & & & & \\
\hline $\mathrm{Na}$ & 0.643 & 0.636 & 1 & & & & & & & & & & \\
\hline $\mathbf{K}$ & 0.15 & 0.233 & 0.585 & 1 & & & & & & & & & \\
\hline $\mathrm{Cl}$ & 0.773 & 0.82 & 0.766 & 0.455 & 1 & & & & & & & & \\
\hline $\mathrm{HCO}_{3}$ & 0.204 & 0.181 & 0.25 & 0.111 & 0.231 & 1 & & & & & & & \\
\hline $\mathrm{NO}_{3}$ & 0.196 & 0.096 & 0.248 & 0.246 & 0.098 & 0.353 & 1 & & & & & & \\
\hline $\mathrm{PO}_{4}$ & -0.067 & 0.005 & 0.117 & 0.234 & -0.004 & 0.102 & 0.395 & 1 & & & & & \\
\hline $\mathrm{SO}_{4}$ & 0.781 & 0.86 & 0.569 & 0.238 & 0.885 & 0.242 & -0.059 & -0.053 & 1 & & & & \\
\hline $\mathrm{H}_{4} \mathrm{SiO}_{4}$ & -0.011 & -0.113 & -0.141 & -0.326 & -0.101 & 0.157 & 0.254 & 0.075 & -0.137 & 1 & & & \\
\hline pH & -0.438 & -0.306 & -0.292 & 0.083 & -0.312 & 0.034 & -0.349 & -0.06 & -0.203 & -0.374 & 1 & & \\
\hline EC & 0.819 & 0.872 & 0.711 & 0.382 & 0.971 & 0.317 & 0.101 & -0.011 & 0.948 & -0.098 & -0.27 & 1 & \\
\hline TDS & 0.781 & 0.823 & 0.731 & 0.413 & 0.964 & 0.379 & 0.142 & -0.011 & 0.917 & -0.067 & -0.232 & 0.987 & 1 \\
\hline \multicolumn{14}{|l|}{ POM } \\
\hline $\mathrm{Ca}$ & 1 & & & & & & & & & & & & \\
\hline Mg & 0.873 & 1 & & & & & & & & & & & \\
\hline $\mathrm{Na}$ & 0.657 & 0.663 & 1 & & & & & & & & & & \\
\hline $\mathbf{K}$ & 0.12 & 0.245 & 0.558 & 1 & & & & & & & & & \\
\hline $\mathrm{Cl}$ & 0.795 & 0.819 & 0.803 & 0.44 & 1 & & & & & & & & \\
\hline $\mathrm{HCO}_{3}$ & 0.269 & 0.255 & 0.409 & 0.171 & 0.375 & 1 & & & & & & & \\
\hline $\mathrm{NO}_{3}$ & 0.161 & -0.019 & 0.248 & 0.219 & 0.091 & 0.255 & 1 & & & & & & \\
\hline $\mathrm{PO}_{4}$ & -0.069 & 0.002 & 0.113 & 0.231 & 0.008 & 0.123 & 0.379 & 1 & & & & & \\
\hline $\mathrm{SO}_{4}$ & 0.814 & 0.872 & 0.58 & 0.217 & 0.864 & 0.326 & -0.053 & -0.043 & 1 & & & & \\
\hline $\mathrm{H}_{4} \mathrm{SiO}_{4}$ & 0.07 & -0.065 & -0.034 & -0.179 & 0.013 & 0.16 & 0.337 & 0.072 & -0.088 & 1 & & & \\
\hline pH & -0.467 & -0.322 & -0.236 & 0.149 & -0.299 & -0.054 & -0.37 & -0.072 & -0.255 & -0.342 & 1 & & \\
\hline EC & 0.825 & 0.867 & 0.722 & 0.356 & 0.963 & 0.419 & 0.065 & -0.008 & 0.952 & -0.008 & -0.288 & 1 & \\
\hline TDS & 0.79 & 0.822 & 0.758 & 0.39 & 0.968 & 0.475 & 0.107 & -0.007 & 0.916 & 0.028 & -0.257 & 0.989 & 1 \\
\hline
\end{tabular}


Table 8: Factor analysis for All season

\begin{tabular}{|c|c|c|c|c|c|c|c|c|c|}
\hline \multicolumn{5}{|c|}{ PRM } & \multicolumn{5}{|c|}{ SWM } \\
\hline \multirow[b]{2}{*}{ Parameters } & \multicolumn{4}{|c|}{ Factor loading } & \multirow{2}{*}{ Parameters } & \multicolumn{4}{|c|}{ Factor loading } \\
\hline & 1 & 2 & 3 & 4 & & 1 & 2 & 3 & 4 \\
\hline $\mathrm{Ca}$ & 0.078 & -0.248 & 0.162 & 0.442 & $\mathrm{Ca}$ & 0.821 & -0.036 & 0.37 & 0.062 \\
\hline Mg & 0.563 & -0.159 & 0.394 & -0.216 & Mg & 0.872 & 0.003 & 0.08 & -0.102 \\
\hline $\mathbf{N a}$ & 0.363 & 0.182 & 0.777 & -0.004 & $\mathrm{Na}$ & 0.769 & 0.329 & -0.172 & 0.081 \\
\hline $\mathbf{K}$ & 0.007 & 0.882 & 0.003 & -0.163 & $\mathbf{K}$ & 0.358 & 0.582 & -0.461 & 0.125 \\
\hline $\mathrm{Cl}$ & 0.241 & 0.005 & 0.924 & -0.096 & $\mathrm{Cl}$ & 0.946 & 0.096 & -0.063 & 0.102 \\
\hline $\mathrm{HCO}_{3}$ & 0.645 & 0.384 & 0.291 & -0.052 & $\mathrm{HCO}_{3}$ & 0.544 & 0.126 & -0.243 & 0.353 \\
\hline $\mathrm{NO}_{3}$ & \begin{tabular}{|l|}
-0.139 \\
\end{tabular} & -0.013 & -0.237 & 0.766 & $\mathrm{NO}_{3}$ & -0.042 & 0.441 & 0.515 & 0.245 \\
\hline $\mathrm{PO}_{4}$ & -0.042 & 0.402 & 0.049 & -0.034 & $\mathrm{PO}_{4}$ & -0.034 & 0.68 & 0.044 & -0.038 \\
\hline $\mathrm{SO}_{4}$ & 0.953 & -0.054 & -0.037 & 0.041 & $\mathrm{SO}_{4}$ & 0.925 & -0.099 & 0.108 & -0.029 \\
\hline $\mathrm{H}_{4} \mathrm{SiO}_{4}$ & 0.064 & 0.374 & 0.342 & 0.33 & $\mathrm{H}_{4} \mathrm{SiO}_{4}$ & 0.016 & -0.026 & 0.192 & 0.888 \\
\hline pH & -0.175 & 0.02 & 0.04 & -0.722 & pH & -0.197 & -0.112 & -0.823 & 0.067 \\
\hline EC & 0.954 & 0.006 & 0.243 & 0.093 & EC & 0.982 & 0.029 & 0.039 & 0.075 \\
\hline TDS & 0.926 & 0.066 & 0.321 & 0.1 & TDS & 0.975 & 0.059 & -0.012 & 0.134 \\
\hline TDV \% & 27.59 & 15.96 & 13.78 & 10.77 & TDV \% & 43.47 & 11.42 & 10.13 & 9.47 \\
\hline \multicolumn{5}{|c|}{ NEM } & \multicolumn{5}{|c|}{ POM } \\
\hline & \multicolumn{4}{|c|}{ Factor loading } & & \multicolumn{4}{|c|}{ Factor loading } \\
\hline Parameters & 1 & 2 & 3 & 4 & Parameters & 1 & 2 & 3 & 4 \\
\hline $\mathbf{C a}$ & 0.867 & 0.076 & 0.004 & 0.271 & $\mathbf{C a}$ & 0.873 & 0.057 & 0.29 & -0.047 \\
\hline Mg & 0.911 & 0.044 & 0.06 & 0.085 & Mg & 0.912 & 0.038 & 0.051 & -0.006 \\
\hline Na & 0.712 & 0.504 & 0.006 & -0.036 & Na & 0.731 & 0.453 & -0.03 & 0.1 \\
\hline $\mathbf{K}$ & 0.308 & 0.703 & 0.1 & -0.454 & $\mathbf{K}$ & 0.282 & 0.709 & -0.433 & 0.207 \\
\hline $\mathrm{Cl}$ & 0.95 & 0.169 & 0.081 & -0.017 & $\mathrm{Cl}$ & 0.944 & 0.165 & 0.001 & 0.148 \\
\hline $\mathrm{HCO}_{3}$ & 0.22 & 0.004 & 0.755 & -0.022 & $\mathrm{HCO}_{3}$ & 0.336 & 0.009 & 0.053 & 0.707 \\
\hline $\mathrm{NO}_{3}$ & -0.02 & 0.536 & 0.564 & 0.365 & $\mathrm{NO}_{3}$ & -0.04 & 0.536 & 0.532 & 0.266 \\
\hline $\mathrm{PO}_{4}$ & -0.148 & 0.649 & 0.24 & 0.059 & $\mathrm{PO}_{4}$ & -0.123 & 0.618 & 0.112 & 0.17 \\
\hline $\mathrm{SO}_{4}$ & \begin{tabular}{|l|}
0.946 \\
\end{tabular} & -0.068 & 0.053 & -0.044 & $\mathrm{SO}_{4}$ & 0.949 & -0.047 & -0.012 & 0.043 \\
\hline $\mathrm{H}_{4} \mathrm{SiO}_{4}$ & -0.147 & -0.104 & 0.328 & 0.761 & $\mathrm{H}_{4} \mathrm{SiO}_{4}$ & -0.099 & -0.029 & 0.714 & 0.448 \\
\hline pH & -0.296 & -0.218 & 0.169 & -0.805 & pH & -0.329 & -0.137 & -0.802 & 0.243 \\
\hline EC & 0.972 & 0.089 & 0.157 & -0.016 & EC & 0.971 & 0.08 & 0.011 & 0.169 \\
\hline TDS & 0.946 & 0.105 & 0.237 & -0.038 & TDS & 0.947 & 0.105 & 0.001 & 0.248 \\
\hline TDV \% & 42.65 & 12.55 & 11.14 & 10.76 & TDV \% & 43.105 & 12.492 & 10.899 & 10.068 \\
\hline
\end{tabular}

\section{Figures}




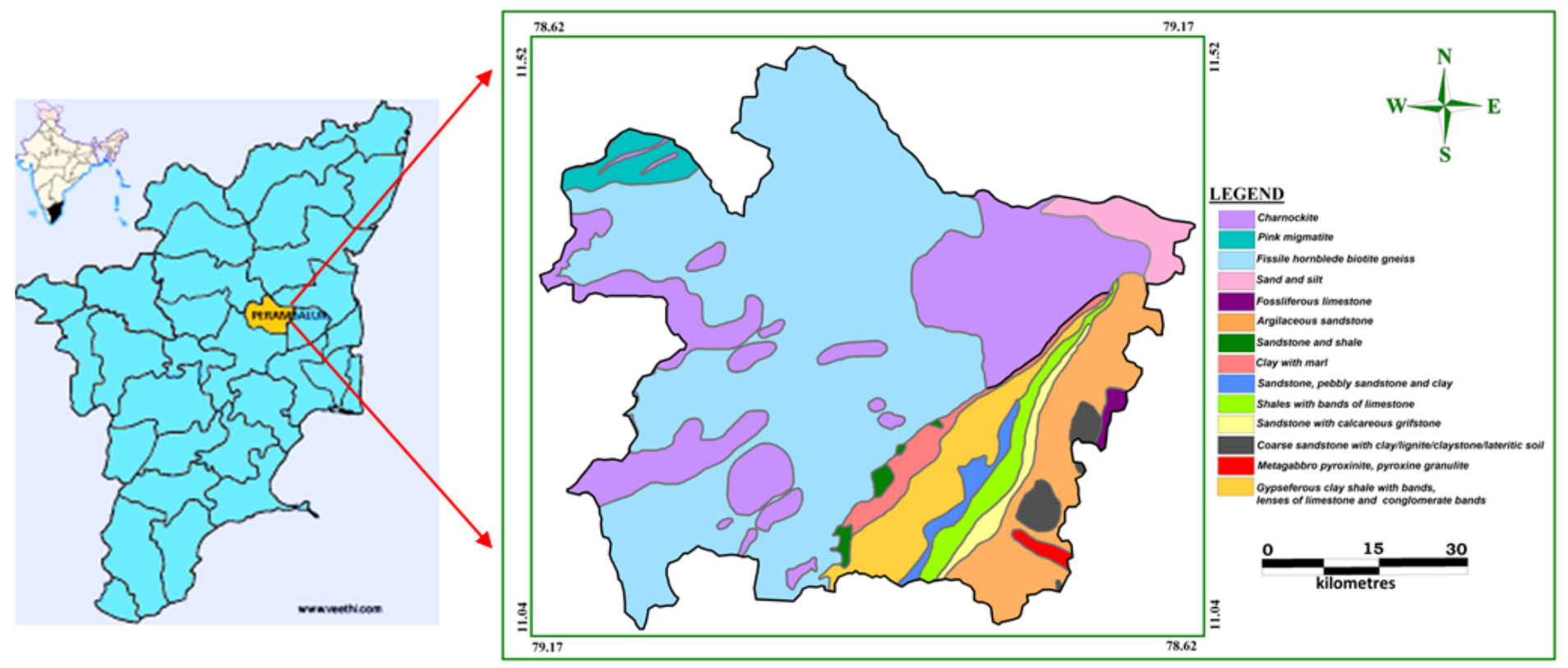

Figure 1

Lithology map of the study area (Modified after GSI, 2006)

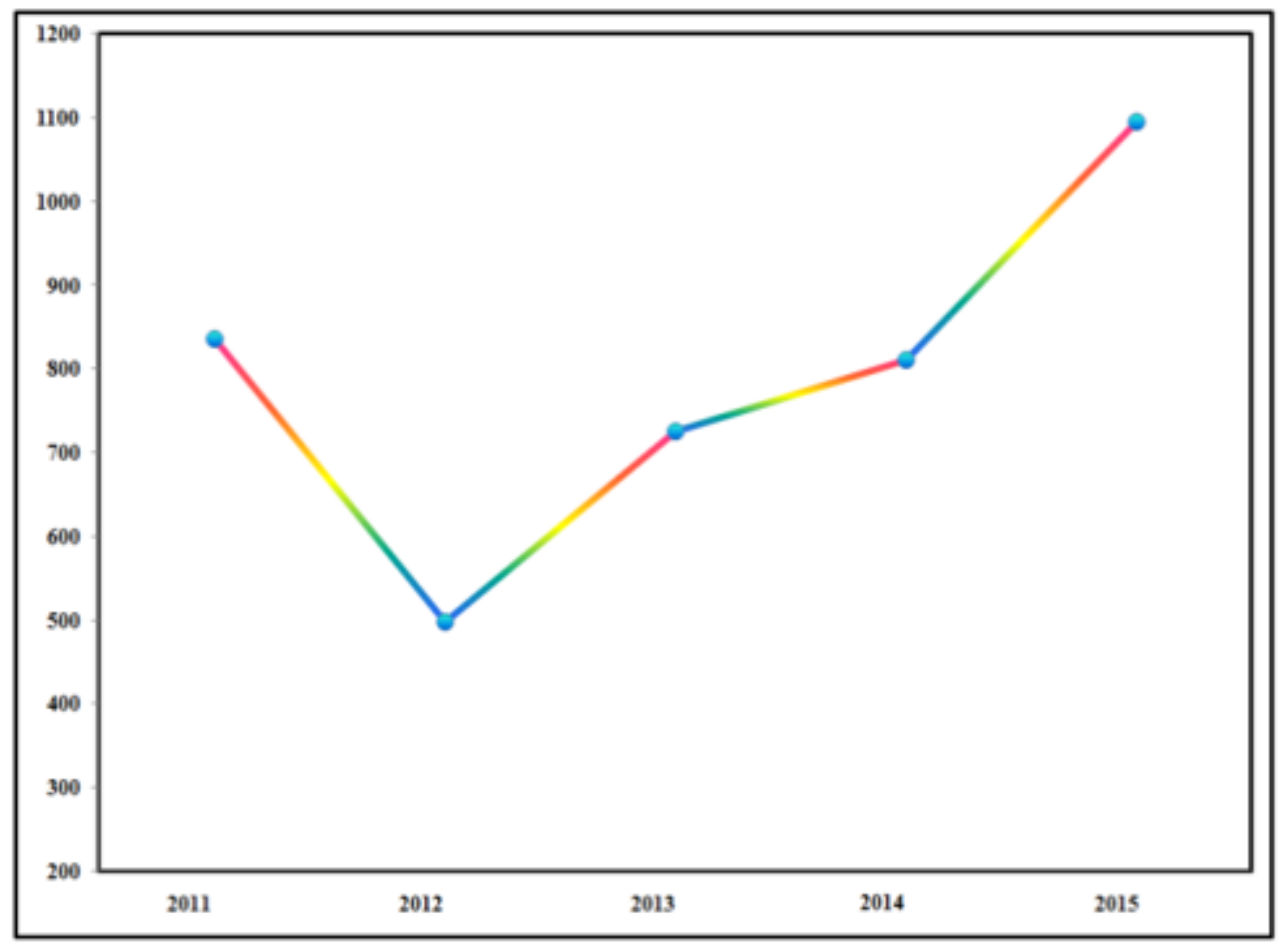

Figure 2

The total annual rainfall for 5 years from 2011 to 2015 of the study regions collected from IMD, Chennai. 

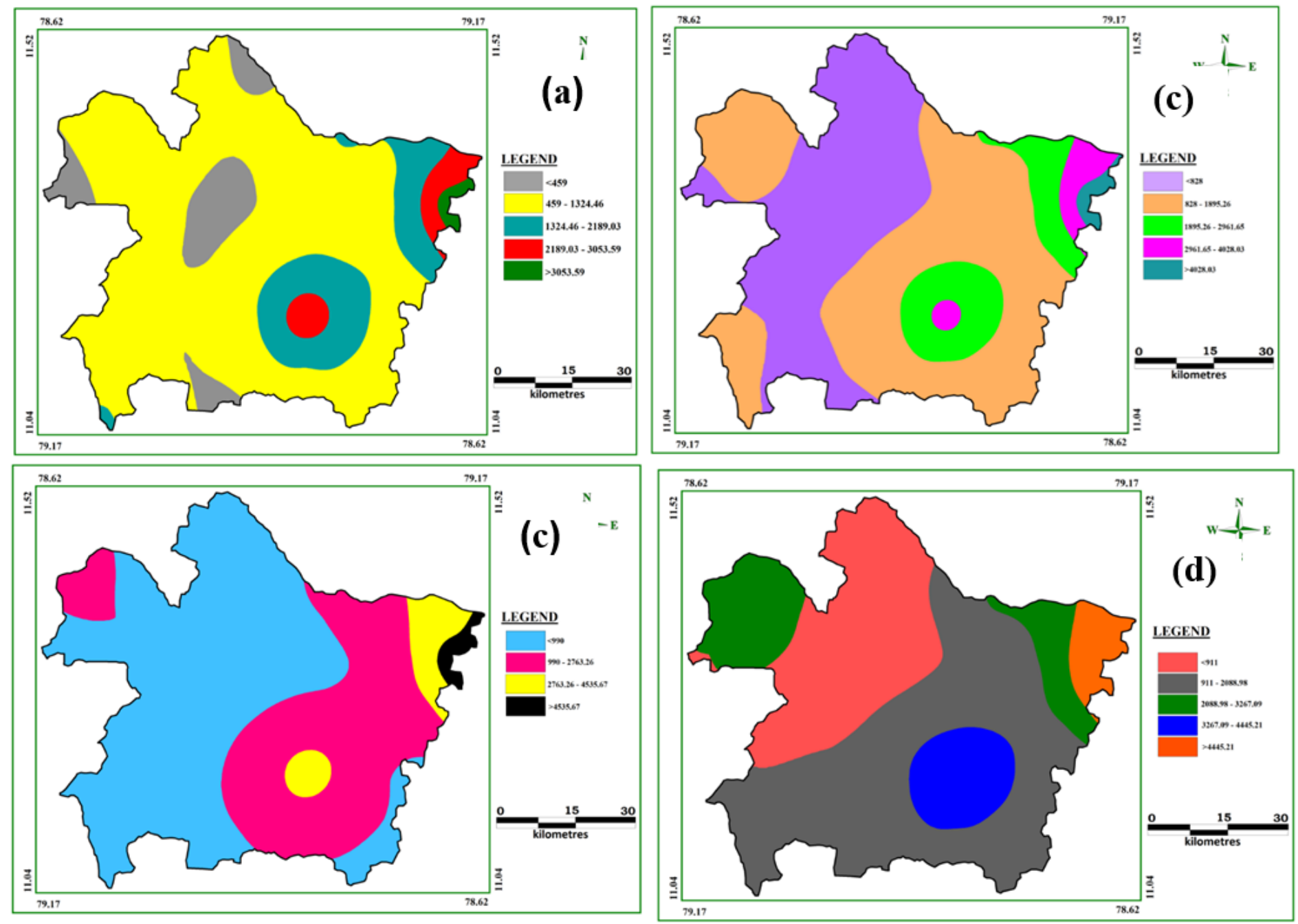

Figure 3

Spatial distribution of EC ( $\mu \mathrm{S} / \mathrm{cm})$ for (a) PRM, (b) SWM, (c) NEM, (d) POM 


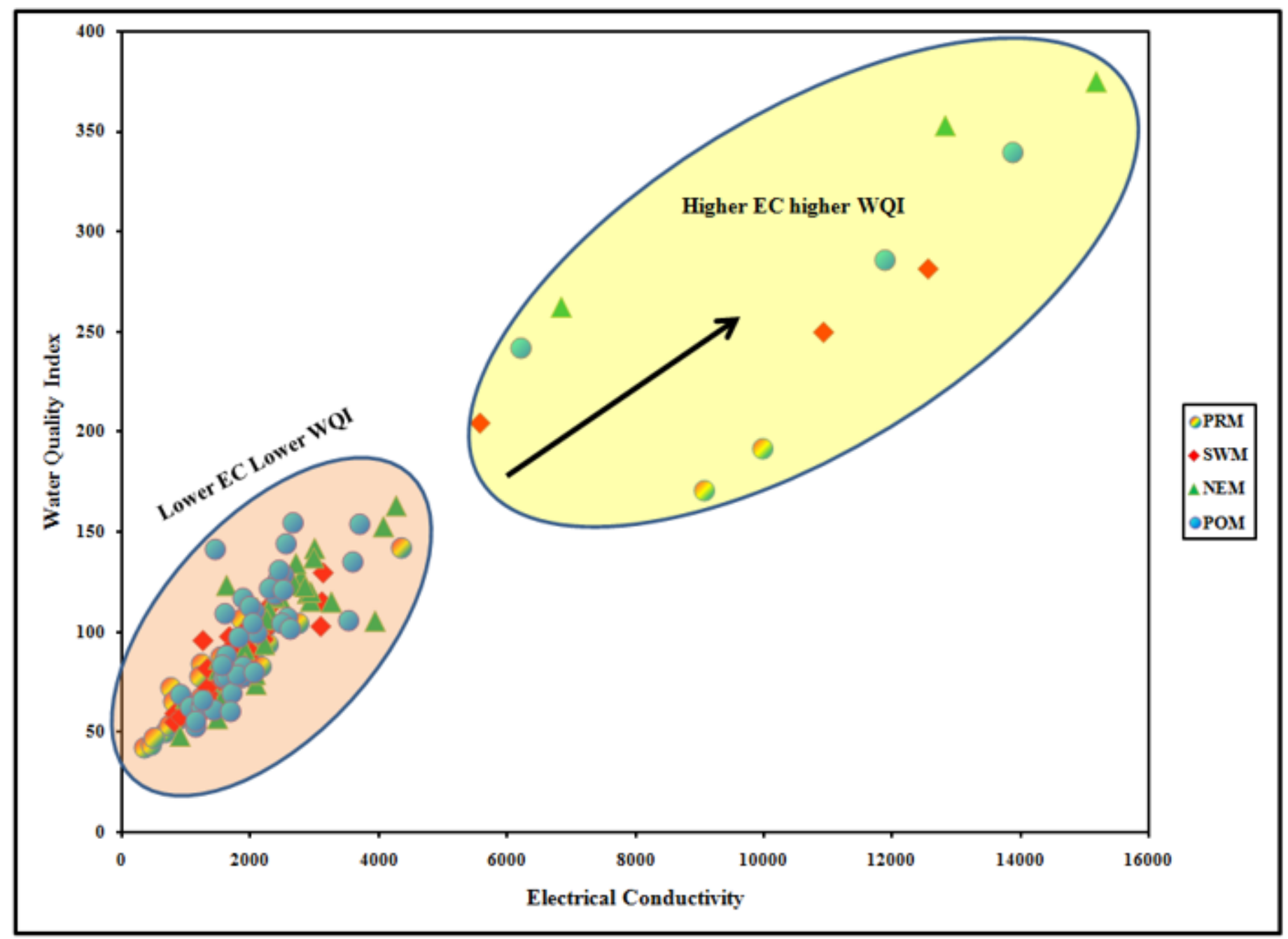

Figure 4

Relationship between EC Vs WQI 

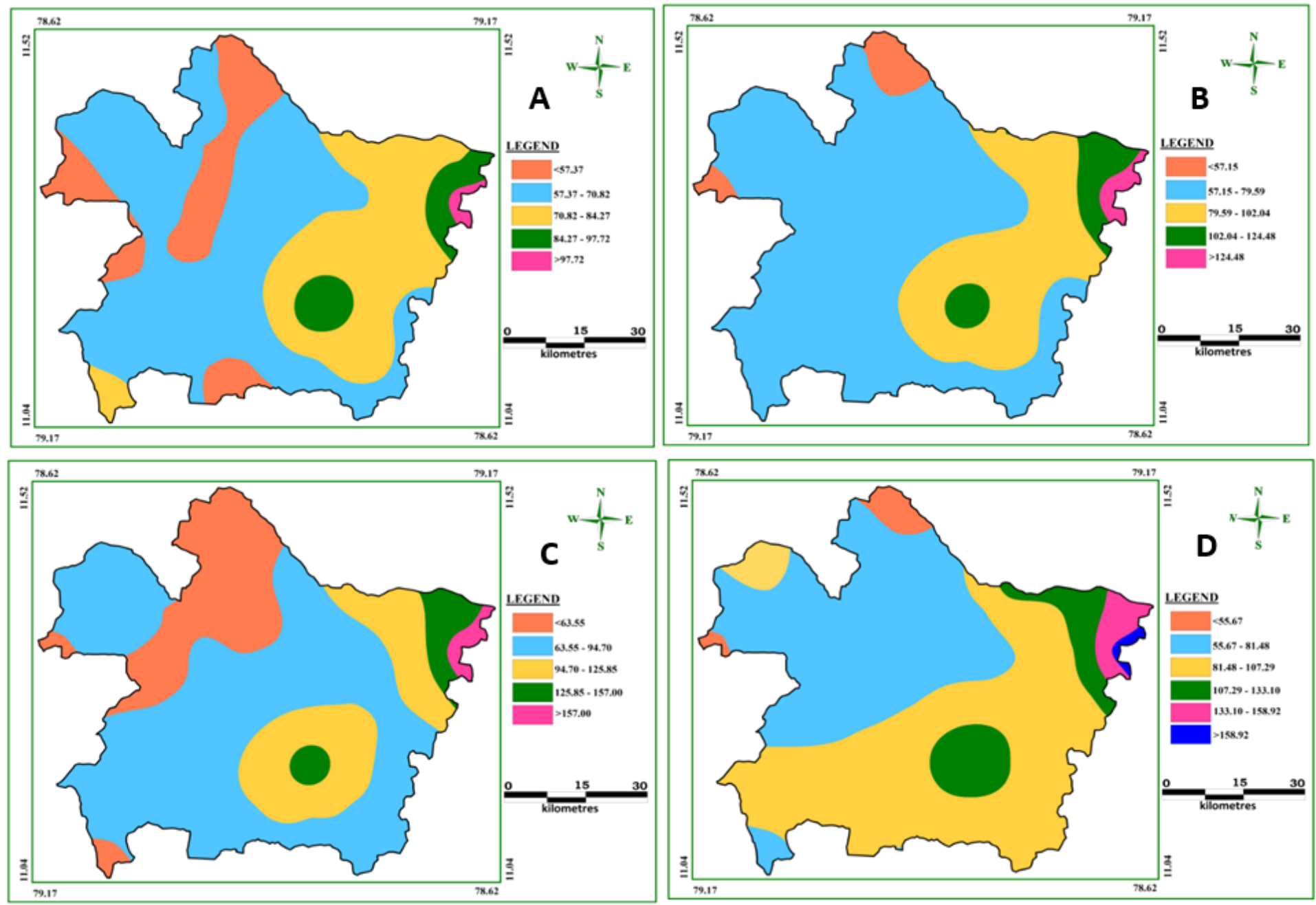

Figure 5

Spatial distribution of Drinking water quality index for (A) PRM, (B) NEM, (C)SWM and (D)POM 


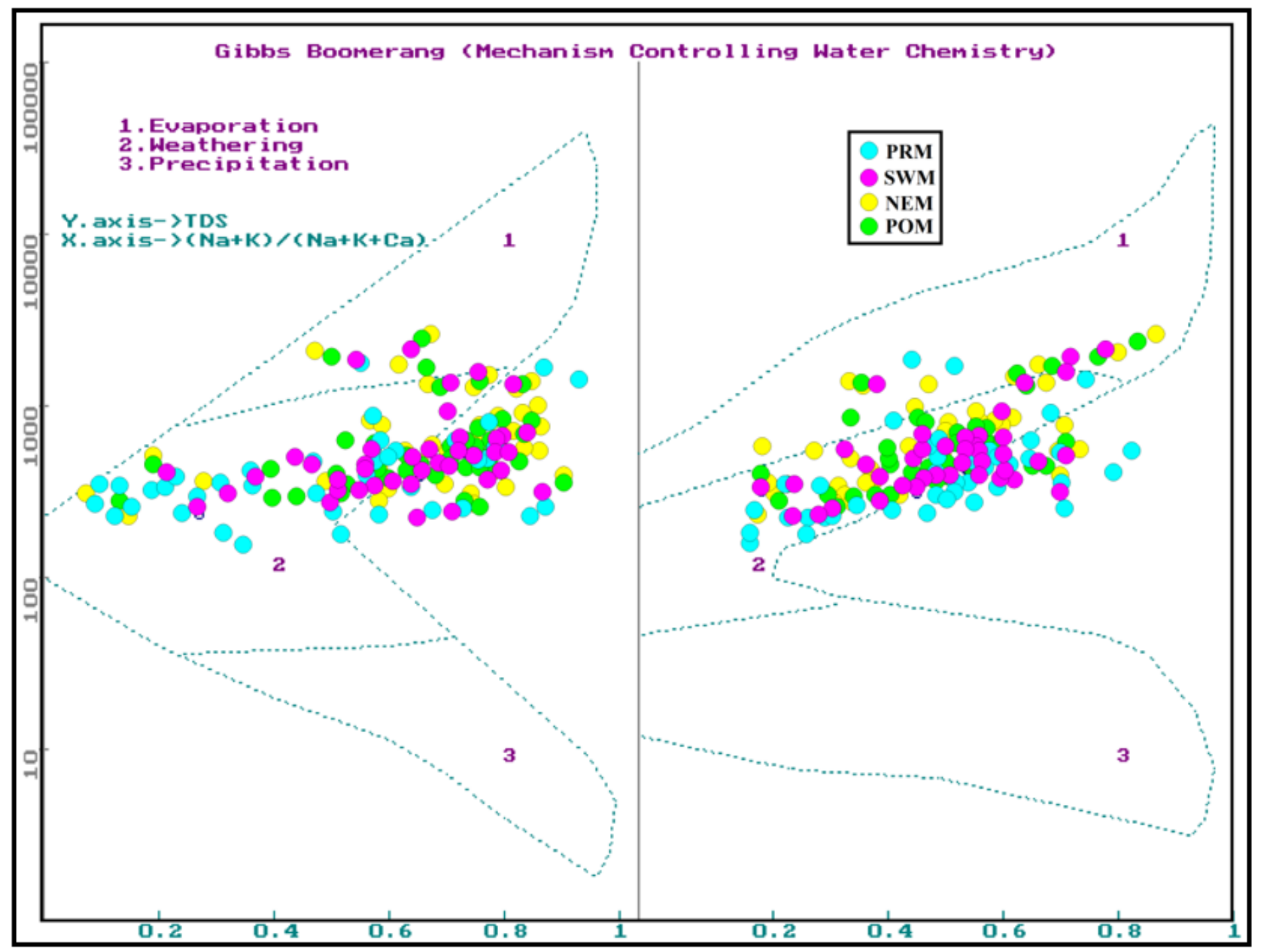

Figure 6

The mechanism for identification of significant geochemical process responsible for the geochemical variation in the groundwater of the study area for all four different season (Gibbs 1970) 


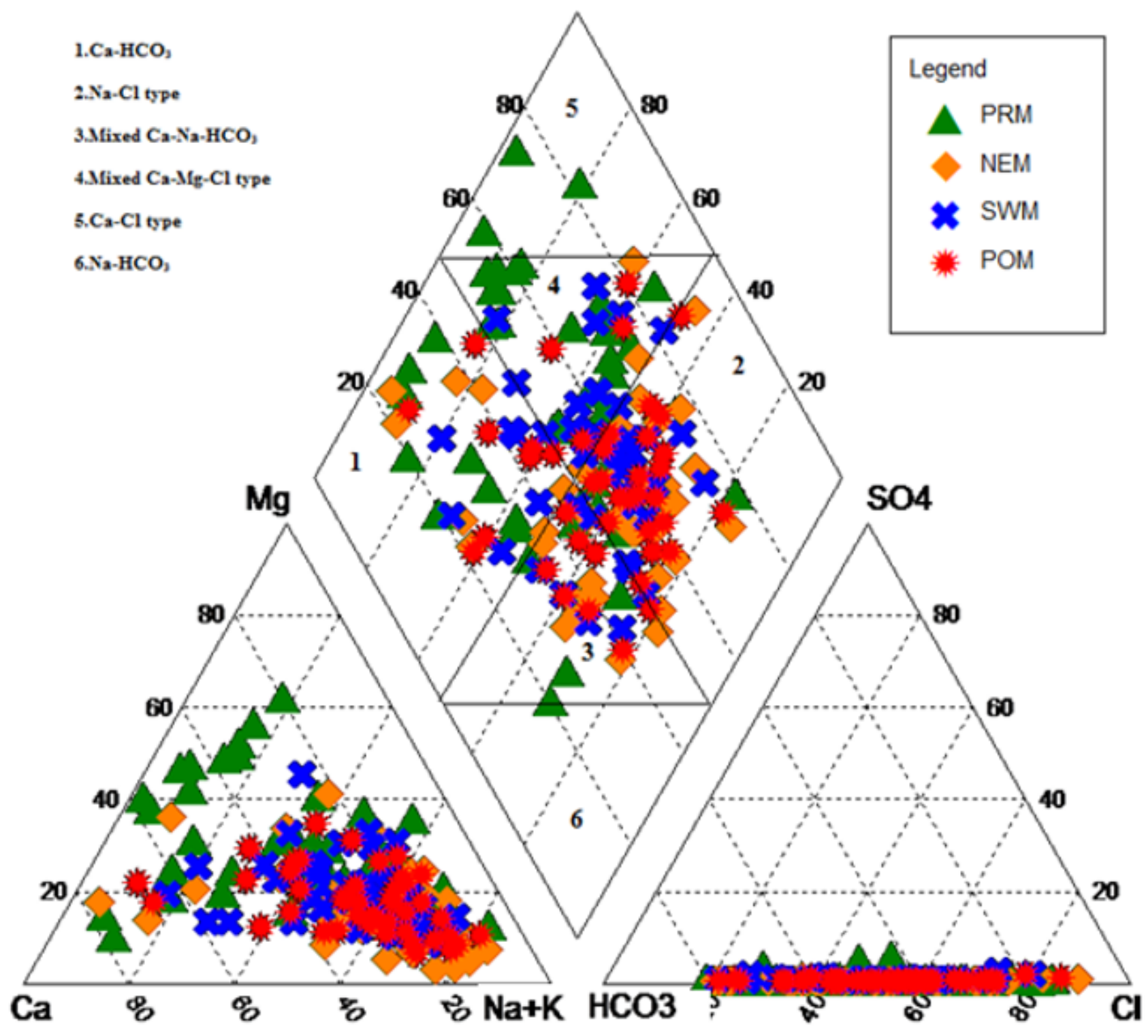

Figure 7

Piper plot exhibiting the chemical facies of groundwater samples for all season 